\title{
Ready for STEM?
}

\section{A Leading Commercial Multimedia Database as a Source for Media-Rich Science, Technology, Engineering, and Mathematics Assets for K-12 Library Collections}

\author{
Marcia A. Mardis
}

National emphases on STEM learning and digital textbooks have highlighted the importance of high quality digital instructional materials. Because teachers often lack the time and expertise to find, assess, and organize multimedia, school librarians can support STEM learning by providing media-rich, current, curriculumlinked library collections. To determine whether Discovery Education Streaming, a leading commercial database is a viable source of school library STEM resources, the researcher analyzed its multimedia assets by media, grade, category, and copyright. Results suggested that the database's extensive content was comprised mainly of video segments, complete videos, and images but that this content was outdated, had uneven grade coverage, and addressed limited topics. While the results raise concerns about Discovery Education Streaming as an enhancement to library collections, careful use of these sources may allow school librarians opportunities to integrate high quality digital assets into their collections through specific strategies for policy, research, and practice.

Marcia A. Mardis (mmardis@fsu.edu) is an Associate Professor at the School of Information at Florida State University in Tallahassee, FL.

Submitted January 28, 2013; returned to author for revision April 3, 2013; revision submitted July 14, 2013; returned to author for additional revision October 7 , 2013; second revision submitted November 2, 2013; accepted for publication July 22, 2014
$\mathrm{E}$ ffective science, technology, engineering, and mathematics (STEM) learn$\checkmark$ ing experiences center on two variables: high quality learning resources and high quality pedagogy; deeply intertwined, neither variable alone is sufficient to improve student achievement. ${ }^{1}$ The role of resources in $\mathrm{K}-12$ education is so crucial that the ability to locate instructional information is a significant driver of teacher quality, and confidence in the ability to integrate available resources can be used as a proxy measure of educator effectiveness. ${ }^{2}$ For these reasons, the school library collection matters. The school librarian is the sole educator tasked with building and maintaining a collection of diverse, high quality, current resources that support curriculum, complement adopted texts, enable professional learning, and pique student interest. Despite the pleas of school library researchers, policymakers, and educators for making instructional collaboration and leadership the defining elements of the school librarian's role, three decades of scholarly researchers have consistently concluded that a well-curated collection 
of learning resources assembled and maintained by a qualified school library professional has a measurable relationship with student achievement. ${ }^{3}$

Current educational initiatives may give the school library collection an even greater role in student learning. The US Department of Education is urging school administrators to focus on two main reform issues: STEM education and digital textbooks. ${ }^{4}$ Policymakers have noted that "the world today's students will inherit will be one defined to an even greater degree by science and technology," "mastery of mathematics, science, and technology is no longer only for future scientists and engineers; it is essential preparation for all students," and that technology tools and digital content are essential components of fostering STEM learning. ${ }^{5}$

Promoting district and state level adoption of digital textbooks, or collections of high quality, interactive digital multimedia learning content, has been at the forefront of federal education initiatives. ${ }^{6}$

Florida has enacted the Digital Learning Now Act (Senate Bill 2120/House Bill 7917) that mandates that public schools will use at least 50 percent digital instructional materials by the 2015-16 school year. ${ }^{7}$ This move was significant not only because Florida is a textbook adoption benchmark state, but also since the law is the first of its kind. Two other states have similar laws. California's legislation encourages, but does not mandate, digital textbooks in public schools by 2020 . In 2010 , Illinois passed legislation redefining textbooks to include digital formats. The Florida law is the most ambitious measure, requiring full implementation of digital textbooks by 2015 , and it is anticipated that other states are soon to follow. ${ }^{8}$

\section{Problem Statement and Significance}

Because STEM is a national priority and is well supported by existing digital materials, digital textbooks will likely first be implemented to support STEM learning. ${ }^{9}$ While many schools make use of free, open education resources (OERs) for STEM learning available through providers like the National Science Foundation's National Science Digital Library (NSDL) (http://nsdl.org), market researchers estimate that over 50 percent of schools rely on commercial content providers. ${ }^{10}$ Discovery Education, the educational programming division of the cable television network Discovery Channel, is attempting to expand its role in the STEM instructional and supplementary materials market. ${ }^{11}$

In July 2013, parent company Discovery Communications, reported that over half of US schools subscribed to and over one million teachers use Discovery Education Streaming products. ${ }^{12}$ At 2013 enrollment levels, these subscription numbers suggest that Discovery Education Streaming users also included more than 15 million students and approximately 15,000 school librarians. ${ }^{13}$ With annual subscription costs starting at approximately $\$ 2,000-\$ 5,000$ per school, this content provider has a great stake in the digital resource market. Therefore, Discovery Education Streaming's ability to provide high quality STEM education resources has significant implications for educators and learners. To this point, the study was guided by the research question: "To what extent can a leading multimedia database complement a school library STEM collection?" After exploring this research question, the paper concludes with an examination of how school librarians might optimize their involvement in the promotion of these and other digital resources.

\section{Literature Review}

Students are expected to use multimedia, particularly video, for STEM learning; accordingly, well over half of classroom teachers reported using digital video daily and that content is commonly recommended by their school librarian. ${ }^{14}$ In many ways, STEM teachers and school librarians are struggling with common reform issues and with documenting their positive impacts within school systems. Nationally, educational policymakers point to faltering STEM reform initiatives and low test scores as trends that will culminate in a population illiterate in science with few students pursuing STEM careers. ${ }^{15}$ As pressure increases to expand datadriven decisions in schools, every component of the learning environment must show a measurable effect. ${ }^{16}$ Yet national STEM learning and teaching standards producing organizations (i.e., National Science Teachers' Association, American Association for the Advancement of Science) seem to fail to recognize the promise of school librarians to support their improvement efforts, nor do school librarians seem to be effective in building needed relationships with STEM educators. ${ }^{17}$ The missions of effective school librarians and STEM teachers have many common and mutually reinforcing elements. ${ }^{18}$ Similarly, the components of contemporary media and information literacy (also known as 21st Century Skills) and STEM literacy have substantial crossover. As table 1 shows, STEM literacy centers on understanding the interrelated nature of scientific content and processes. ${ }^{19}$

Likewise, twenty-first century skills embody multiple literacies (e.g., textual, visual, numerical, media, information), complex thinking, deep conceptual understanding, and analytical decision-making. ${ }^{20}$ The National Research Council affirmed that scientific understanding is dependent on the interplay of broad cognitive skills and domain-specific learning. ${ }^{21}$ Despite this common ground, close coordination between STEM teachers and school librarians does not frequently occur. ${ }^{22}$ 
Table 1. Definitions of Science, Technology, Engineering and Mathematics Literacy

\begin{tabular}{ll}
\hline Scientific Literacy & $\begin{array}{l}\text { The ability to use scientific knowledge and processes to understand the natural world as well as the ability to par- } \\
\text { ticipate in decisions that affect it in three main areas-science in life and health, science in Earth and environ- } \\
\text { ment, and science in technology. }\end{array}$ \\
\hline Technological Literacy & $\begin{array}{l}\text { Students should know how to use new technologies, understand how new technologies are developed, and have } \\
\text { the skills to analyze how new technologies affect our nation, the world, and us. }\end{array}$ \\
Engineering Literacy & $\begin{array}{l}\text { The understanding of how technologies are developed via the engineering design process using project-based les- } \\
\text { sons in a manner that integrated lessons across multiple subjects. }\end{array}$ \\
Mathematical Literacy & $\begin{array}{l}\text { The ability of students to analyze, reason, and communicate ideas effectively as they pose, formulate, solve, and } \\
\text { interpret problems in a variety of situations. }\end{array}$
\end{tabular}

\section{STEM Collections in Secondary School Libraries}

Building STEM collections has proven particularly challenging for school librarians. Many school librarians struggle with collection development in STEM fields as they often lack formal education in these disciplines. ${ }^{23}$ STEM information changes quickly and content in published books becomes outdated before they can be placed on library shelves. As a result, staying abreast of developments in STEM to maintain a current collection may be one of the most daunting tasks a school librarian faces. ${ }^{24}$ As a participant in a study pointed out, "In science, anything past seven years old is practically worthless." 25

A good resource base can be a point of departure to a richer set of integrative activities and leadership opportunities. The potential for positive impacts on student engagement and achievement through school library collections and from school librarian-teacher collaboration have been demonstrated in previous studies. ${ }^{26}$ School librarians provide collaborative instruction, professional development, and direct student assistance with the use of learning resources in schools with high student achievement. ${ }^{27}$ Some studies have concluded that student science test scores had a statistically significant positive correlation with many specific features of the school library collection such as digital resources and current periodical subscriptions. ${ }^{28}$

Mardis and Hoffman found that STEM books as old as forty years were on many school library shelves. ${ }^{29}$ In a later study, Mardis also found that since school librarians have typically been educated as English or social studies teachers, they were not confident in selecting STEM materials and tolerated old STEM collections. This lack of confidence affected school librarians' willingness to forge relationships with STEM teachers. Despite this reluctance, many school librarians expressed the desire, which was often unrealized due to budget constraints, to add more current journals, databases, and multimedia resources to their collections. ${ }^{30}$ Adding nonbook media seems to have the potential to address deficiencies in STEM book collections with current, dynamic, and affordable digital materials, but many school librarians are unsure where to begin. ${ }^{31}$

\section{STEM Digital Resources in School Libraries}

School librarians are increasingly interested in including digital resources, especially video and audio, in their recommendations to teachers. The 2,025 librarians reflected in the 2012 annual national SpeakUp! longitudinal survey report of educators, parents, and students administered by the independent educational consulting company Project Tomorrow stated selection priorities of

- content accuracy;

- ease of use by teacher and student;

- alignment with state and national curriculum standards;

- credibility of the organization producing materials; and

- flexibility of content for a variety of uses. ${ }^{32}$

Indeed, fostering visual literacy, particularly in relationship to building interdisciplinary understanding is gaining profile as an important function of the school librarian. ${ }^{33}$

\section{Digital Video}

Research on digital video in US schools is an emerging area of study in $\mathrm{K}-12$ education, to date characterized by research limited to specific sites, funded by video-producing companies, or proprietary and released only in summary form. ${ }^{34}$ For example, highlights from a study conducted by the Grunwald Associates research firm for the Public Broadcasting Service (PBS) in 2010 are only included in a PBS press release. ${ }^{35}$ Highlights from this study indicated the benefits of the use of video derived from PBS television programming in the classroom but information about the study sample, questionnaire, or analysis process was not available. Earlier studies emphasized the power of video to facilitate science and mathematics learning. ${ }^{36}$ However, many of these studies were conducted ten years or more years ago, and 
curriculum standards, educational technology, and content providers have changed dramatically in the ensuing years. Research has not kept pace with the advancement of streaming video adoption and use.

This paucity body of research on the use of educational digital streaming video is problematic considering the prevalence of teachers' streaming media use and the instructional differentiation afforded by video technology. With the current growth of freely available web-based video services such as YouTube and TeacherTube (www.teachertube.com/) plus web 2.0 tools for content creation and manipulation, digital video use in the classroom is poised for rapid expansion in ways that may not yet be easily predicted.

Discovery Education Streaming (formerly United Streaming) is a leading subscription multimedia database used by more than 1 million educators and 30 million students in US schools. ${ }^{37}$ Commissioned studies in Virginia and California have suggested positive relationships between the frequency of use of Discovery Education Streaming and grades 3-8 student achievement in state test results for mathematics and reading. Similar positive relationships have been observed with science learning in Virginia. In Florida, 2009 state test scores were 7.4 percent higher in schools that used Discovery Education Streaming. ${ }^{38}$

Not all users felt that Discovery Education streaming benefits were easy to attain. Statewide users in Michigan appreciated the tool's potential as a strong means to introduce new concepts or to allow students to work independently, especially in science. However, educators reported that they found video segments and videos to be outdated, often of poor quality, and the use of the system placed an undue bandwidth usage and network traffic burden on the district or school. Educators listed lack of time to find and preview videos, equipment to project videos to classes, and implementation support as barriers to unfettered use of Discovery Education Streaming. Despite the fact that school librarians are commonly left out of adoption decisions, many serve on the front lines of implementation, assisting teachers with bandwidth capacity management and hardware troubleshooting. ${ }^{39}$

The use of nonprint and visual resources as learning tools has been underemphasized in science curricula and, even when included, unless the resources are accompanied with sufficient metadata to allow them to be adequately indexed by search engines and described in sufficient detail for users to assess their relevance, can be difficult to find and organize. ${ }^{40}$ School librarians have a professional imperative to lead and facilitate the integration of multimedia, including subscription databases, into teaching and learning. ${ }^{41}$ Research led by Mardis suggests that school librarians and STEM teacher collaboration has the potential to enhance the science curriculum using digital video, audio, and applications to teachers but did not systematically integrate digital resources from subscription databases into their collections, thus complicating teachers' and learners' attempts to find and use them. ${ }^{42}$

\section{School Librarian Collaboration with STEM Teachers}

While the potential exists for positive outcomes in school librarian-STEM teacher collaborations, previous research has identified persistent barriers. In studies of middle school STEM teachers, Mardis reported that educators struggled to find high quality digital resources and lacked both the time and experience to adequately evaluate the results of their own Internet searches for quality and appropriateness of content to match curriculum and standards. ${ }^{43}$ Despite teachers' strong desire to include digital resources in their curriculum, researchers have documented teachers' lack of information searching and digital resources quality assessment skills for nearly a decade. Further, teachers recognize the need for on-site assistance to better integrate open content and engage their computer-savvy students with interactive, visual, and up-to-date STEM resources. ${ }^{44}$

Mardis and Perrault showed that in schools where the school librarian collaborated with STEM teachers, there was a significant, positive relationship with student achievement and that strong STEM collections were the key to building relationships with STEM learners. When the STEM teacher and the school librarian provided learning opportunities with digital content to students, those students mastered course content and sustained interest in the STEM topic. ${ }^{45}$ Accordingly, a national report concluded that the more teachers and administrators see the school librarian as a leader in technology integration, the more likely their perceptions will change and their expectations will increase, thus improving instruction and student learning. ${ }^{46}$

In situations where collaboration with STEM teachers occurred on a minimal level, school librarian interactions with STEM teachers took place through information resource provision and teaching STEM students information skills to complete their assignments. These interactions, with the school librarian primarily acting as a resource provider and an instructor of information skills, affirm previous findings. ${ }^{47}$ Empowering the school librarian to focus on current and dynamic sources of STEM information may be the key to promoting those resources to STEM teachers and students and to effective collaboration.

\section{Research Method}

The goal of this study was to explore the extent to which Discovery Education Streaming could enhance school library 
collections. The sample, data collection procedure, and analysis process for each data set is detailed below.

\section{Description of the Sample}

Data were collected on July 7 and 9, 2012, when the Discovery Education Streaming K-12 digital media library database contained approximately 148,000 multimedia assets accessible through browsing categories for Careers/ Workplace Skills; English/Language Arts; Health; Mathematics; Research/Study Skills; Science; Social Studies; Teaching Practices; Visual and Performing Arts; and World Languages. From these categories, the researcher selected for analysis the following three categories: Science, Health, and Mathematics. Discovery Education Streaming developers assigned Science assets into seven subcategories: Earth/ Space Science; History and Nature of Science; Inquiry; Life Science; Physical Science; Science and Technology; and Science in Personal and Social Perspectives. The researcher treated the Science and Technology subcategory as a proxy for a Technology category. Mathematics assets were assigned to subcategories of Algebra; Calculus; Data Analysis and Probability; Geometry; Measurement; Numbers and Operations; Problem Solving; and Trigonometry. Health assets were subcategorized in Alcohol and other Drugs; Growth and Development; Mental Health; Nutrition; Physical Activity; Safety; The Body; Tobacco; and Violence.

Engineering assets, which do not have their own dedicated browsing category or subcategory in Discovery Education Streaming, were retrieved by the researcher through a keyword search of the entire database for the word of "engineering." Engineering assets were not analyzed in subcategories because Discovery Education Streaming does not organize assets on this topic into browsing categories. Engineering assets $(N=600)$ were located through a keyword search of the term "engineering in the entire Discovery Education Streaming database."

\section{Data Collection}

To mimic the typical Discovery Education Streaming user experience, the researcher used the subscriber interface to collect data on July 7 (Health), July 8 (Mathematics and Engineering), and July 9 (Science), 2012. Due to additions to and withdrawals from the resource collection, database asset counts change daily. Therefore, to aid analysis precision and study replication, data for each category were collected on a single day. The researcher reviewed the Discovery Education Streaming database and recorded asset counts by subject, asset type, and grade level. Local content was excluded from asset counts and the range of possible media types is illustrated in table 2 below.

For each subcategory, the researcher narrowed the
Table 2. All Media Types for Discovery Education Streaming Science, Technology, Engineering, and Mathematics Assets

\begin{tabular}{ll}
\hline Activity & Image \\
Assignment & (Math) Overview \\
(Content) Collection & Quiz \\
Encyclopedia Entry & Reading Excerpt \\
(Math) Explanation & Segment (of a Video) \\
Exploration & (Interactive) Simulation \\
Fun-Damental & Skill Builder \\
Game & Song (Music with Singing \\
Guide & (Full) Video \\
\hline
\end{tabular}

view display to the five copyright date ranges available: 1988 or older, 1989-93, 1994-98, 1999-2003, or 2004 or newer. Within each copyright date range, the researcher narrowed the display four times to display the results from only one grade level band, i.e., to $\mathrm{K}-2,3-5,6-8$, and $9-12$, at a time. For each data collection point, the researcher marked the results and exported the results as comma separated value (CSV) files.

\section{Data Analysis}

Data were initially analyzed using the Statistical Package for the Social Sciences (SPSS). Case summary reports reflecting descriptive and frequency statistics were generated for each of the four subject category areas. The case reports were also exported to Excel to create the tables and charts displayed in the Results section of this paper. Within the case summary reports, Science and Health results were analyzed by grade level, copyright date, and subcategory. Technology is included in the Science subcategory of "Science and Technology." Mathematics assets were analyzed by grade level and subcategory. Because the Engineering category was not subcategorized, no results could be obtained from browsing. All Engineering results were obtained via keyword search of the Discover Streaming database.

\section{Results}

This section presents frequency analyses of Discovery Education Streaming assets in separate subsections for science, engineering, mathematics, and health.

\section{Science Assets}

On the date of data collection (July 9, 2012), Discovery Education Streaming contained 71,702 science assets assigned to eight subcategories. First, all assets in the Science category 
Table 3. Science Assets by Grade Level, Media Type, Copyright Date, and Subject Classification $(N=71,702)$

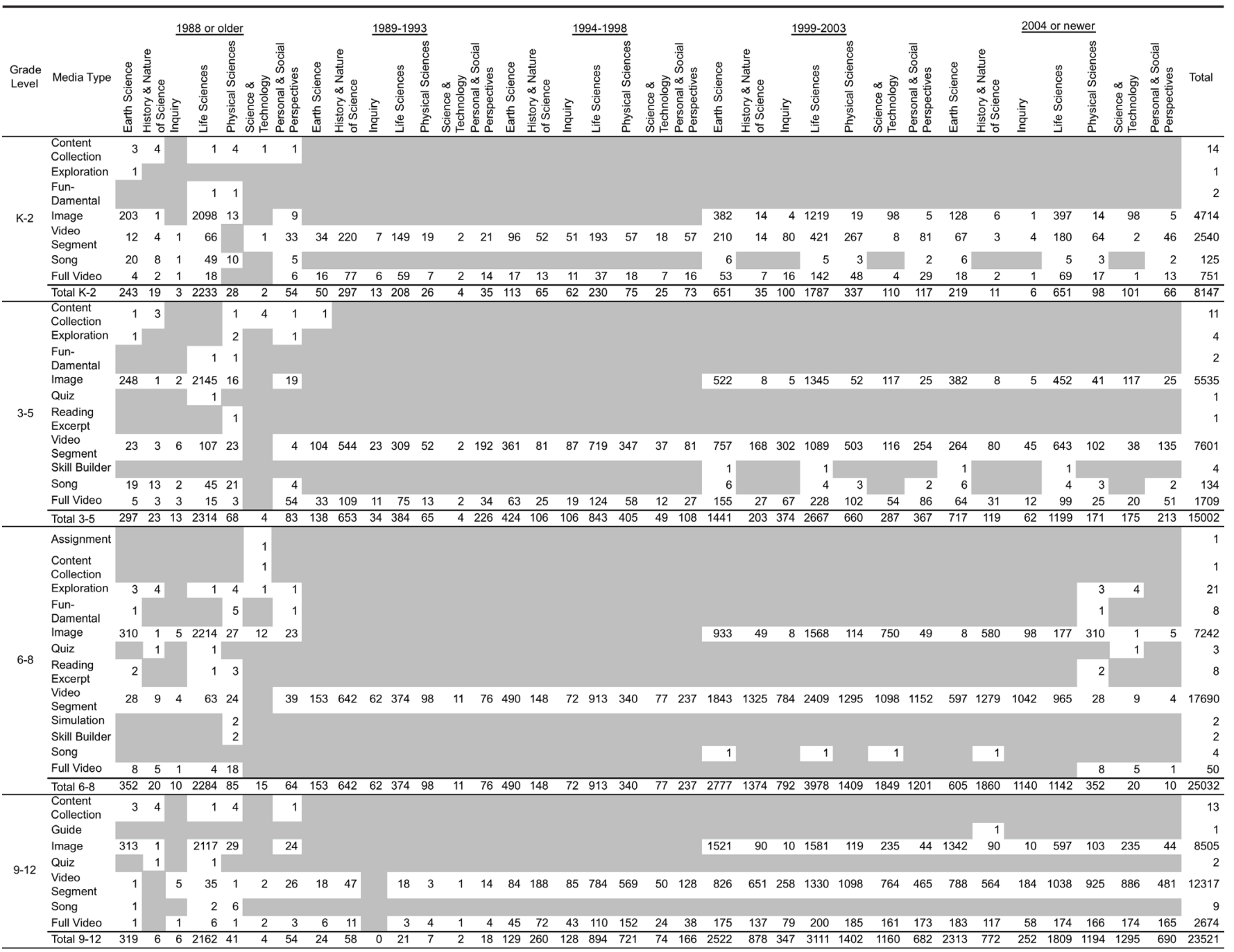

were analyzed. Table 3 illustrates the distribution of these resources across media type, grade level, and subcategory. As table 3 shows, assets are not distributed equally across subjects and media types.

The majority of Discovery Education Streaming assets are assigned types of video segment $(n=40,148$ or 55 percent), image ( $n=25,996$ or 36 percent), and/or full video $(n=5,184$ or 7 percent). The remaining media types represented about 2 percent of assets. Records for the Science category's assets were examined by grade level, and subcategory. Table 2 illustrates the results. The distribution of assets across grade bands was 25,032 (34 percent) assigned to grades $6-8 ; 23,521$ (32 percent) to grades $9-12 ; 15,002$ (20 percent) to grades $3-5$; and 8,147 (11 percent) to grades $\mathrm{K}-2$. It should be noted that the remaining 3 percent difference possibly reflects rounding and asset assignment to multiple grade bands. Figure 1 further illustrates the distribution of science assets across grade levels and categories

As figure 1 indicates, most asset records were assigned to the Life Sciences subcategory with 29,204 (40 percent) records, followed by Earth/Space Sciences with 13,977 (19 percent), Physical Science with 7,582 (10 percent) and History and Nature of Science with 7,549 (10 percent). The least number of records were assigned to the Science and Technology subcategory with 5,268 (7 percent); Science in Personal and Social Perspectives with 4,540 (6 percent); and Inquiry with 3,582 (4 percent). Total percentages reflect rounding and asset assignment to multiple subcategories.

\section{Engineering Assets}

Engineering assets $(N=600)$ were examined by media type and grade level. Discovery Education Streaming does not provide browsing subcategories in the Engineering category, 


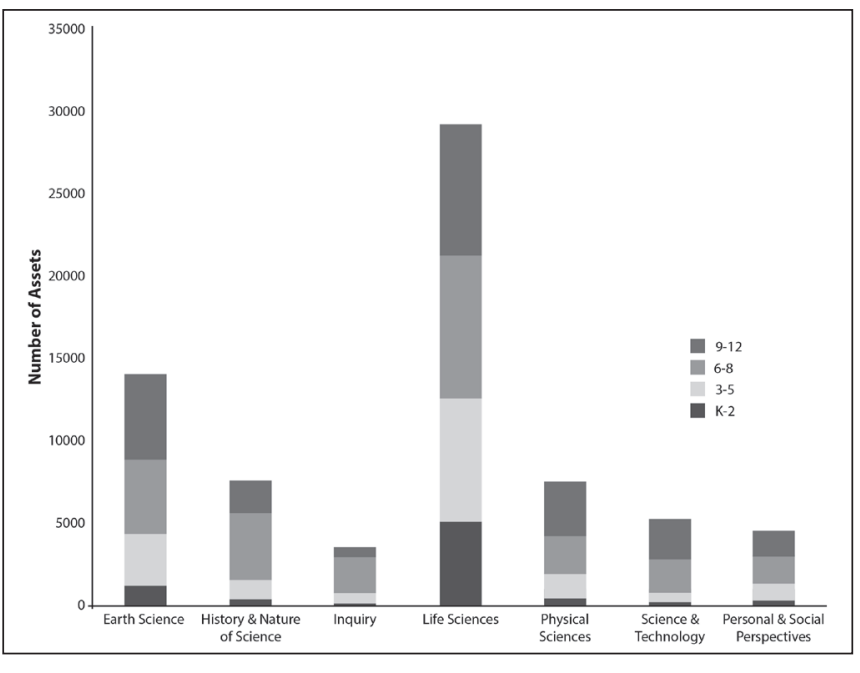

Figure 1. Science Assets by Subcategory and Grade Level $(N=71,702)$

so results were obtained via keyword search. Table 4 illustrates the asset distribution across media type, grade level, and copyright date.

As table 4 shows, the most predominant media types were Video Segment ( $n=317$ or 52 percent) and Full Video $(n=214$ or 35 percent). The remaining assets were comprised of Images $(n=49$ or 8 percent), Encyclopedia Entries ( $\mathrm{n}=14$ or 2 percent). Activity $(n=2$ or 1.5 percent) and Content Collection ( $n=2$ or 1.5 percent) account for the remaining 3 percent of media types. Most engineering resources were for grades $6-8$ ( $n=388$ or 64 percent $)$ and grades $9-12$ ( $n=168$ or 28 percent). The remaining fortyfour assets ( 8 percent) were for students in grades $\mathrm{K}-5$. The majority of the assets had copyright dates 1999-2003 $(n=340$ or 56 percent) and 2004 or newer $(n=260$ or 43 percent).

\section{Mathematics Assets: Media Type, Grade Level, and Subcategory}

Discovery Education Streaming included 13,743 assets in the Mathematics category on the date of data collection (July 8,2012 ). Table 5 illustrates the distribution of assets in the Mathematics browsing category across grade level, media type, and subcategory.

As table 5 shows, assets are not distributed equally across media types. The majority of Discovery Education Streaming assets are assigned types of "segment" (an edited portion of a video) ( $n=10,906$ or 79 percent), full video ( $n$ $=2,112$ or 15 percent), and song (recorded music and lyrics) ( $n=491$ or 3 percent). The remaining 234 (3 percent) assets represented other media types. Media types are listed and defined in table 2 .
Records for Mathematics assets were then examined by grade level, and subcategory. The distribution of assets across grade bands was 4,547 (33 percent) to grades 9-12; 3,812 (27 percent) assigned to grades 6-8; 2,695 (19 percent) to grades $\mathrm{K}-2$; and 2,689 (19 percent) to grades $3-5$. It should be noted that the remaining 2 percent difference perhaps reflects rounding and asset assignment to multiple grade bands (see figure 2).

Assets were assigned to eight subcategories. Most asset records were assigned to Numbers and Operations with 4,031 (29 percent), followed by Problem Solving with 2,915 (21 percent) records Algebra with 1,875 (13 percent), Geometry with 1773 (12 percent), Data Analysis and Probability with 1,429 (10 percent), and Measurement with 1,217 (8 percent). The fewest records were assigned Calculus and Trigonometry accounted for 2 percent. Total percentages reflect rounding and asset assignment to multiple subcategories.

\section{Health Assets}

On the date of data collection (July 8, 2012), Discovery Education Streaming included 14,603 assets in the Health category. Table 6 illustrates the distribution of assets in the Health browsing category across grade level, media type, subcategory, and copyright date.

Table 6 shows that the number of assets varies across media types, grade levels, and subcategories. The majority of Discovery Education Streaming Health assets were assigned types of video segment ( $n=7786$ or 53 percent), image ( $n$ $=4,507$ or 30 percent), and/or full video ( $n=2,048$ or 14 percent). The remaining media types represented about 3 percent of assets.

Records for Health assets were then examined by grade level, and subcategory. Table 6 illustrates the results. The distribution of assets across grade bands was 5,001 (34 percent) assigned to grades $9-12 ; 4,770$ (32 percent) to grades $6-8$; 2,646 (18 percent) to grades $\mathrm{K}-2$; and 2,186 (14 percent) to grades $3-5$. It should be noted that the remaining 2 percent difference possibly reflects rounding and asset assignment to multiple grade bands. Figure 4 further illustrates the distribution of science assets across grade levels and categories.

Figure 3 shows that most asset records were assigned Nutrition with 3,408 (23 percent); Growth and Development with 3,406 (23 percent); The Body (1,592 or 10 percent); Physical Activity with 1,490 (10 percent); and Mental Health with 1,430 (9 percent) followed by Safety with 1,390 (9 percent); and Alcohol with 1,236 (8 percent). The fewest records were assigned Violence (486 or 3 percent) and Tobacco (165 or 1 percent). Total percentages reflect rounding and asset assignment to multiple subcategories. 
Table 4. Engineering Assets for K-12 by Grade Level, Media Type, and Copyright Date $(N=600)$

\begin{tabular}{|c|c|c|c|c|c|c|c|}
\hline Grade Level & Media Type & 1988 or older & 1989-1993 & 1994-1998 & 1999-2003 & 2004 or newer & Total \\
\hline \multirow{4}{*}{ K-2 } & $\begin{array}{l}\text { Content Collection } \\
\text { Image }\end{array}$ & 1 & & & & & $\begin{array}{l}1 \\
5\end{array}$ \\
\hline & Video Segment & & & & 2 & & 2 \\
\hline & Full Video & & & & 1 & & \\
\hline & Total K-2 & 1 & 0 & 0 & 3 & 5 & 9 \\
\hline \multirow{5}{*}{ 3-5 } & Content Collection & 1 & & & & & 1 \\
\hline & Image & & & & 2 & 6 & 8 \\
\hline & Video Segment & & & 4 & 2 & 3 & 9 \\
\hline & Full Video & & & 1 & 11 & 5 & 17 \\
\hline & Total 3-5 & 1 & 0 & $\frac{1}{5}$ & $\frac{11}{15}$ & $\frac{5}{14}$ & $\frac{11}{35}$ \\
\hline \multirow{5}{*}{$6-8$} & Content Collection & 1 & & & & & 1 \\
\hline & Image & & & & 6 & 15 & 21 \\
\hline & Video Segment & & & 6 & 93 & 143 & 242 \\
\hline & Full Video & & & 2 & 55 & 67 & 124 \\
\hline & Total 6-8 & 1 & $\overline{0}$ & 8 & 154 & 225 & 388 \\
\hline \multirow{7}{*}{$9-12$} & Activity & & & & & $\frac{220}{2}$ & $\frac{300}{2}$ \\
\hline & Content Collection & 1 & & & & & 1 \\
\hline & Encyclopedia Entry & & & & & 14 & 14 \\
\hline & Image & & & & 15 & & 15 \\
\hline & Video Segment & & 2 & 8 & 54 & & 64 \\
\hline & Full Video & & 1 & 18 & 53 & & 72 \\
\hline & Total 9-12 & 1 & $\frac{1}{3}$ & 26 & 122 & 16 & 168 \\
\hline Total All Gra & de Levels & 4 & 3 & 39 & 294 & 260 & 600 \\
\hline
\end{tabular}

\section{All STEM Assets: Media Type and Copyright Date}

Assets were analyzed in aggregate for an overall impression of media type, grade level, subcategory, and copyright date distribution. Figure 4 reflects media types across all categories and grade levels.

As the figure shows, video segments $(n=59,157$ or 59 percent) and images or ( $n=30,608$ or 30 percent), full videos $(n=9,558$ or 9 percent), and songs (1,003 or 1 percent) comprised the majority of Discovery Education Streaming STEM assets. The final 1 percent of assets was comprised of the remaining media types listed in table 2 .

Figure 5 illustrates a comparison of copyright dates for all subject categories, which reflect that the majority $(75,636$ or 83 percent) of assets are older than seven years. As demonstrated by figure 5 , science is the category with the most assets (71,702 or 71 percent) and most of the science assets $(54,440$ or 79 percent) are older than seven years. Health assets are the second largest STEM category with nearly 14 percent $(14,603)$ and 73 percent $(10,646)$ of those assets seven years or older. Math assets comprised almost another 14 percent $(13,743)$ and 73 percent of them were older than seven years. The remaining 1 percent of assets related to engineering topics and 57 percent (340) had copyright dates older than 2003.

\section{Discussion}

With a national move toward digital textbooks driving an imperative for greater integration of STEM digital content, the researcher for this study sought to determine the extent to which Discovery Education Streaming could function as a source of high quality, readily available multimedia learning assets. National digital textbooks and STEM learning focuses create a unique opportunity for school librarians to upgrade and expand their collections, demonstrate technology leadership, and show themselves to be effective and relevant instructional partners with STEM teachers. In pursuit of an answer to the question of whether the Discovery Education Streaming database is a viable source of STEM content, its assets in science and technology, engineering, mathematics, and health were analyzed by media type, grade level, subject category and subcategory, and copyright date to address a research question relating to extent and quality of the collection.

\section{To What Extent Can a Leading Multimedia Database Complement a School Library STEM Collection?}

Research has demonstrated that teachers benefit from support in identifying high quality instructional materials but that school librarians are often frustrated in their attempts to support STEM learning and promote digital materials into school library collections. This analysis revealed that Discovery Education Streaming could be a potential source of multimedia content for school library collections because it contains more than 100,000 assets in science, technology, engineering, mathematics, and health. Science was the largest category, followed by health; technology and engineering topics represented the smallest number of STEM-related assets. Topically, Discovery Education Streaming appeared to be a good source of content for life sciences, algebra, numbers and operations, and nutrition. Discovery Education streaming also appeared to be a better source for assets for grades 3 and higher, with a concentration on upper elementary and middle grades. While assets in the Health category were plentiful, they were lacking in the Tobacco and Violence subcategories, and these topics are important aspects of learning about healthy lifestyles. Mathematics also appeared to be short on support for important advanced topics such as Trigonometry and Calculus. Science was astonishingly low on assets in the Inquiry category-an important topic to which school librarians can definitely contribute content and process.

The modest asset counts in the Science and Technology and Engineering subcategories are a concern because proponents of STEM education reform advocate increasing the visibility of technology and engineering in the standard $\mathrm{K}-12$ curriculum. Technology and engineering relate to the ways that humans modify the natural environment and therefore it is essential that STEM learning be "expanded to include all kinds of devices, instruments, and tools that can be applied in both domains of science and engineering." 48

As its name suggests, Discovery Education Streaming contains a significant amount of streaming video segments and full videos. It also contains a large number of images. Given that content providers range from broadcast sources including the Discovery Channel and PBS and governmental organizations such as NASA and Smithsonian, it is likely that 
Table 5. Mathematics Assets for K-12 by Grade Level, Media Type, and Copyright Date $(N=13,743)$

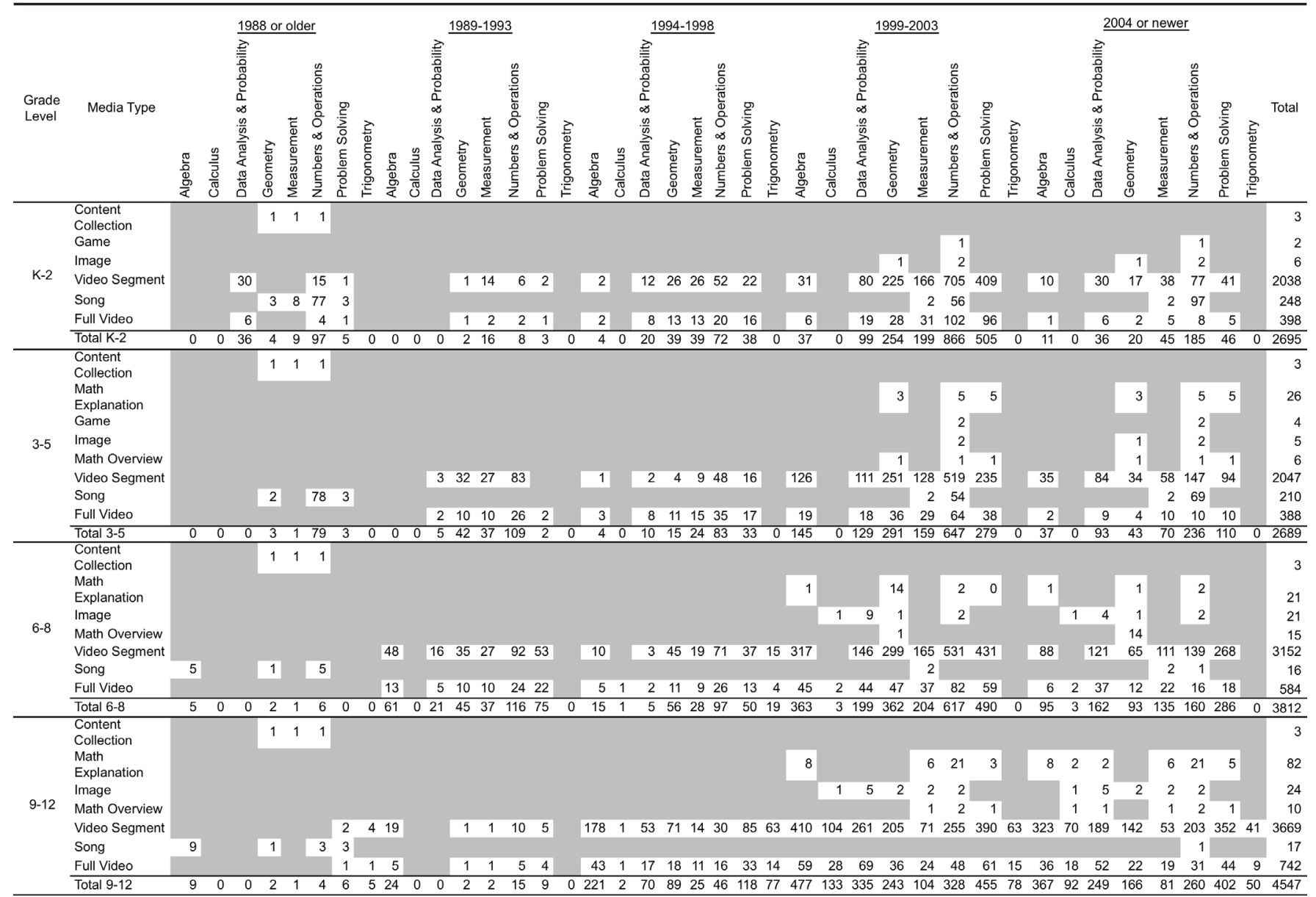

the content of those visual assets reflects accurate science and good quality production. However, the age of the assets in Discovery Education Streaming exceeded seven years, a collection development threshold for STEM resources. In particular, science, engineering, technology and health are highly dynamic fields with rapid advances in knowledge and application occurring constantly. Older or dated resources in these areas run the risk of containing inaccurate or incomplete information and potentially misleading learners.

\section{Limitations and Future Research}

This study has limitations, including the fact that Discovery Education Streaming asset counts change daily. While efforts were made to analyze all assets in a particular category, the constantly changing asset counts may undermine efforts to replicate the study using the most current database contents. Additionally, neither engineering nor technology were topics represented in Discovery Education Streaming with browsing categories, and using keyword searches of the database to identify assets related to engineering topics may

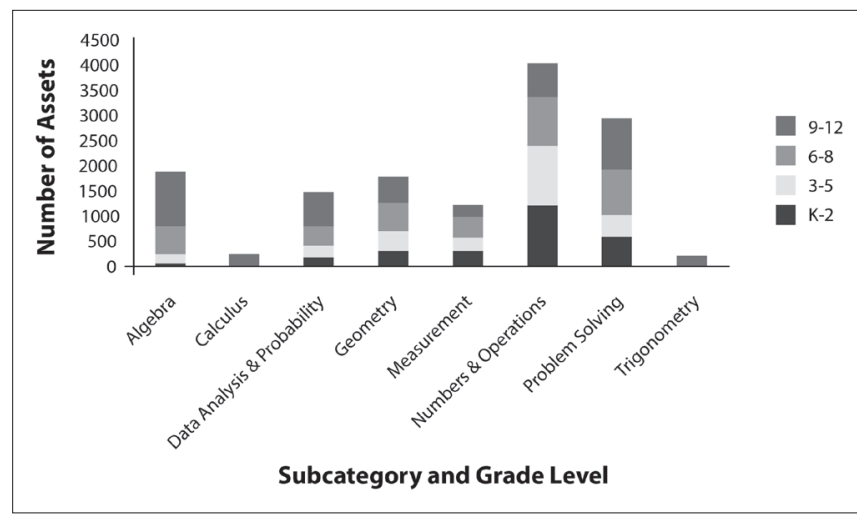

Figure 2. Mathematics Assets by Subcategory and Grade Level $(N=13,743)$

have resulted in the exclusion of relevant assets. Other concerns relate to whether the subject areas with lower numbers reflect of a lack of available $\mathrm{K}-12$ resources in general or whether they are disproportionately underrepresented in 


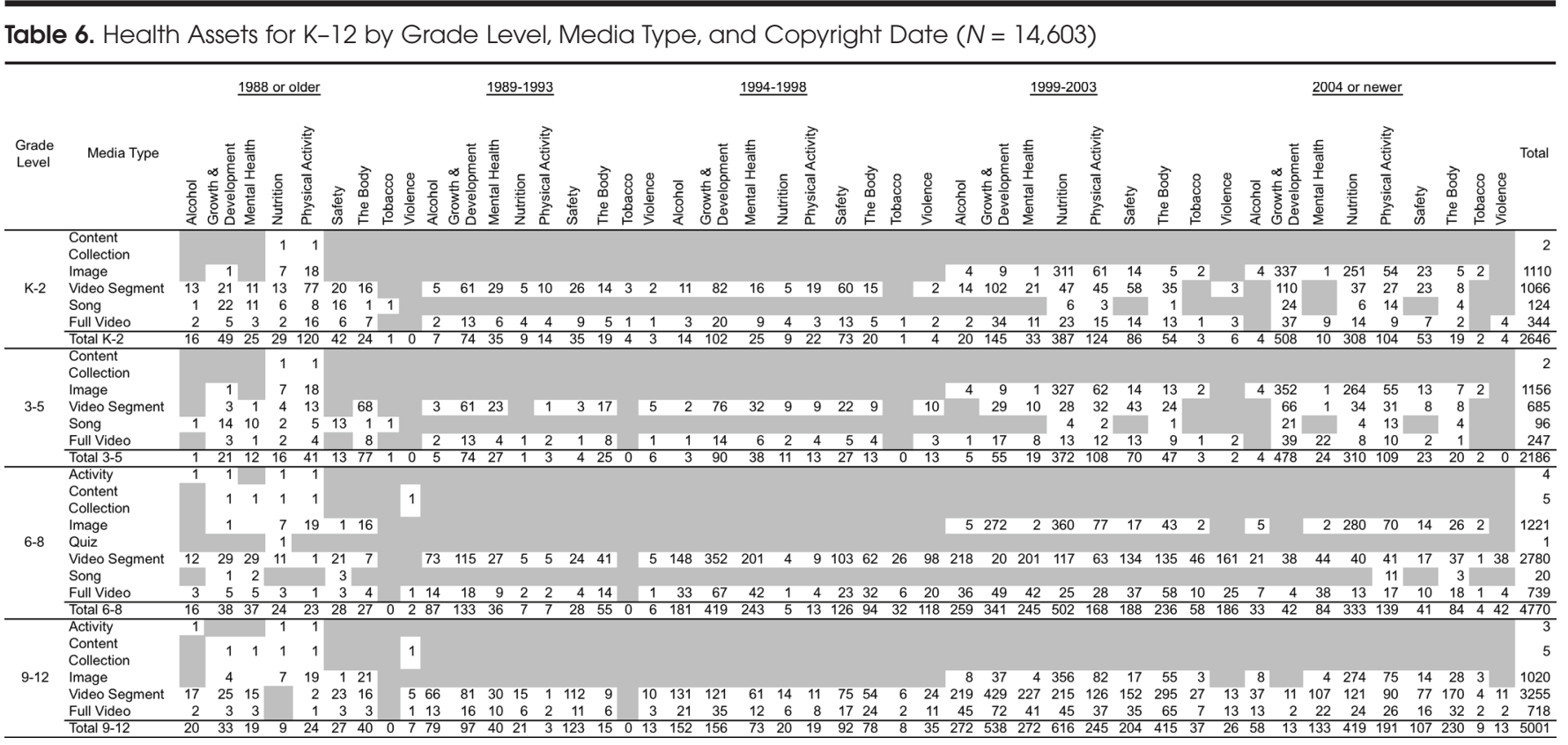

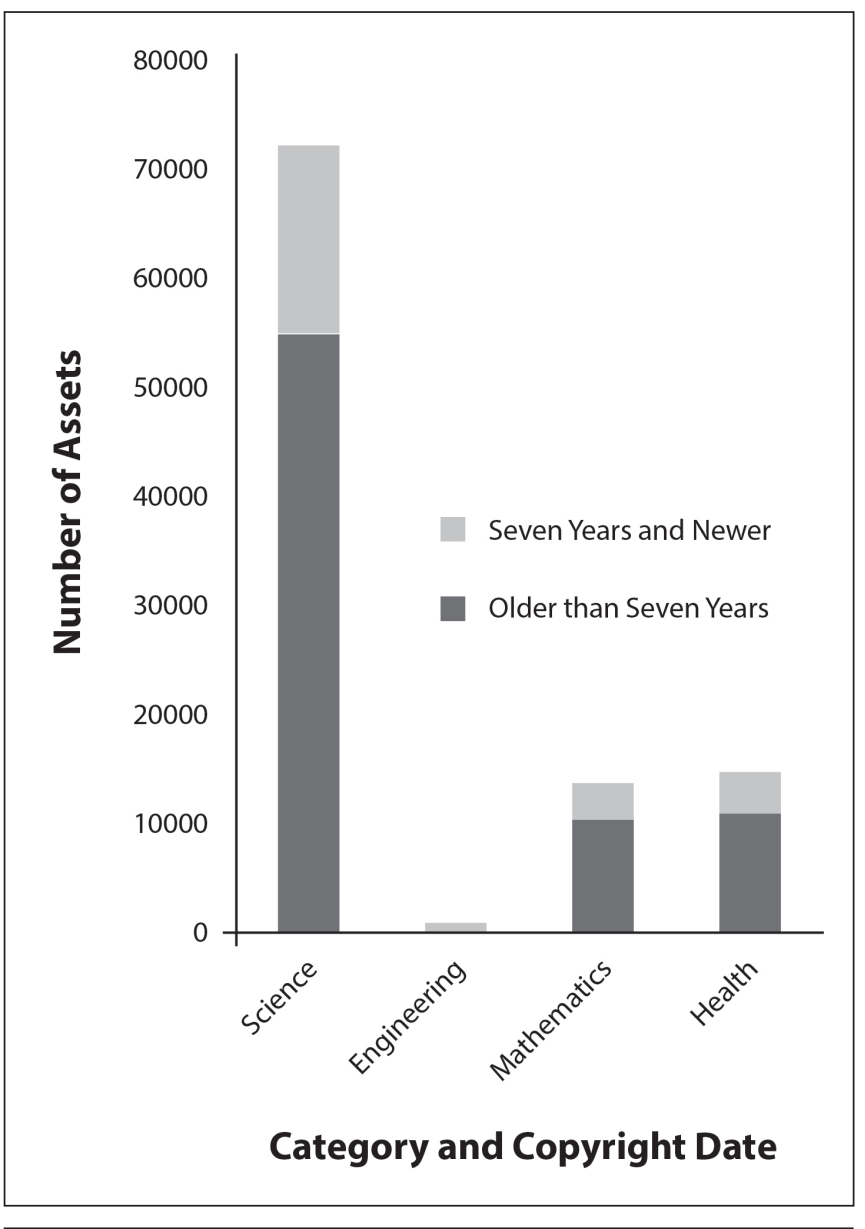

Figure 3. Health Assets by Subcategory and Grade Level $(N=14,603)$ the database. It is possible that there are there competing databases that differ substantially from Discovery Education Streaming in the scope of their content. However, considering Discovery Education Streaming's domination of the market, the researcher chose not to focus on possible resources, but on the most readily available resources to teachers, librarians, and students in US schools.

Ultimately, asset quantity differs from asset quality, and to gauge the true value of Discovery Education Streaming multimedia assets to a school library collection, one may need to do more than count them. This study was an attempt to gain an idea of the extent of the Discovery Education streaming's collection and a starting point for further research. For example, researchers may wish to use a similar descriptive approach to characterize the contents of other resource databases or delve further into which Discovery Education Streaming resources are actually use by educators and learners.

\section{Conclusion}

For school librarians, focusing on STEM education and digital instructional materials may provide tremendous opportunities to work closely with teachers and to bring attention to the school library collection. While the collection development activities of the school librarian may be downplayed in professional guidelines and policy discussions, it is nonetheless a powerful and versatile role. With teachers trying to determine how to find and integrate high quality digital resources through digital textbook and STEM reform initiatives, school librarians can provide important 


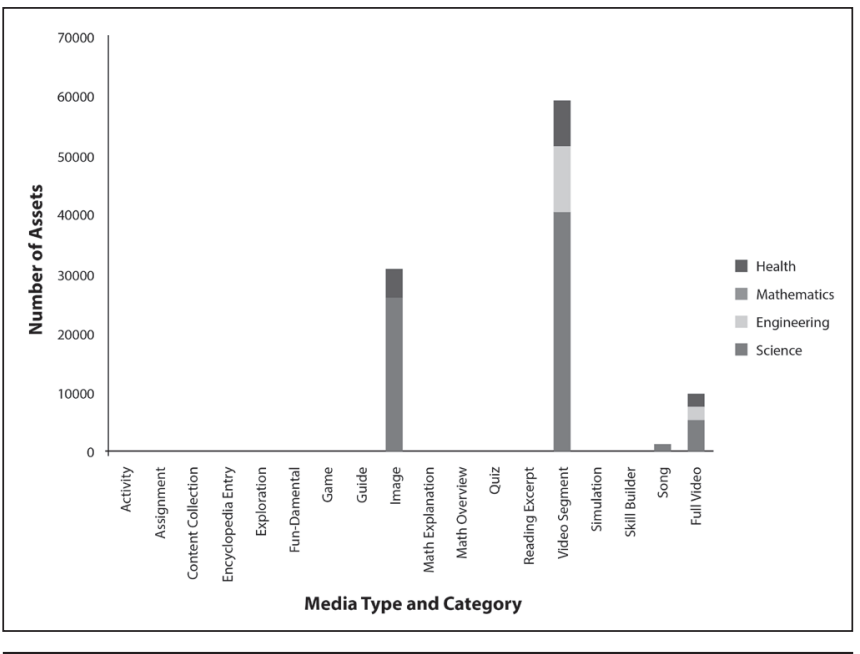

Figure 4. Comparison of All Media Types Across Category $(N=100,649)$

input on instructional materials selection. By definition, the school library collection is a source of supplementary curriculum materials and unless those resources are linked to the classroom curriculum, they will not be visible and will be of little or no use to the teaching process.

Aside from obvious actions such as taking part in discussions of instructional materials selection, school librarians may benefit from an awareness of the various ways their stakeholders encounter library resources: through outreach to administrators, teachers, parents, and students; through their library websites, pathfinders, and newsletters; and importantly, through library catalogs. Discovery Education Streaming resources, carefully reviewed by school librarians for topical relevancy and currency, can be promoted through these vehicles along with other learning assets available in the school.

Popular library management systems like Follett Library Software's Destiny and COMPanion's Alexandria products include federated search functions and execute a single search to be executed across library resources and databases, including Discovery Education Streaming. Library catalog records can be created for individual Discovery Education Streaming resources with free tools similar to Web2MARC (http://dl2sl.org/web2marc).

School librarians may help their school administrators to determine whether an investment in Discovery Education Streaming is worthwhile by surveying teachers about their use and their needs. Web analytics can track traffic to the Discovery Education Streaming website and provide school librarians with data about time and extent of access that can inform technology policies and future expenditures. Greater use of streaming video requires investments in network infrastructure and training for support professionals and this falls under the leadership aegis of a strong school librarian.

Instructional partnering and teaching are additional

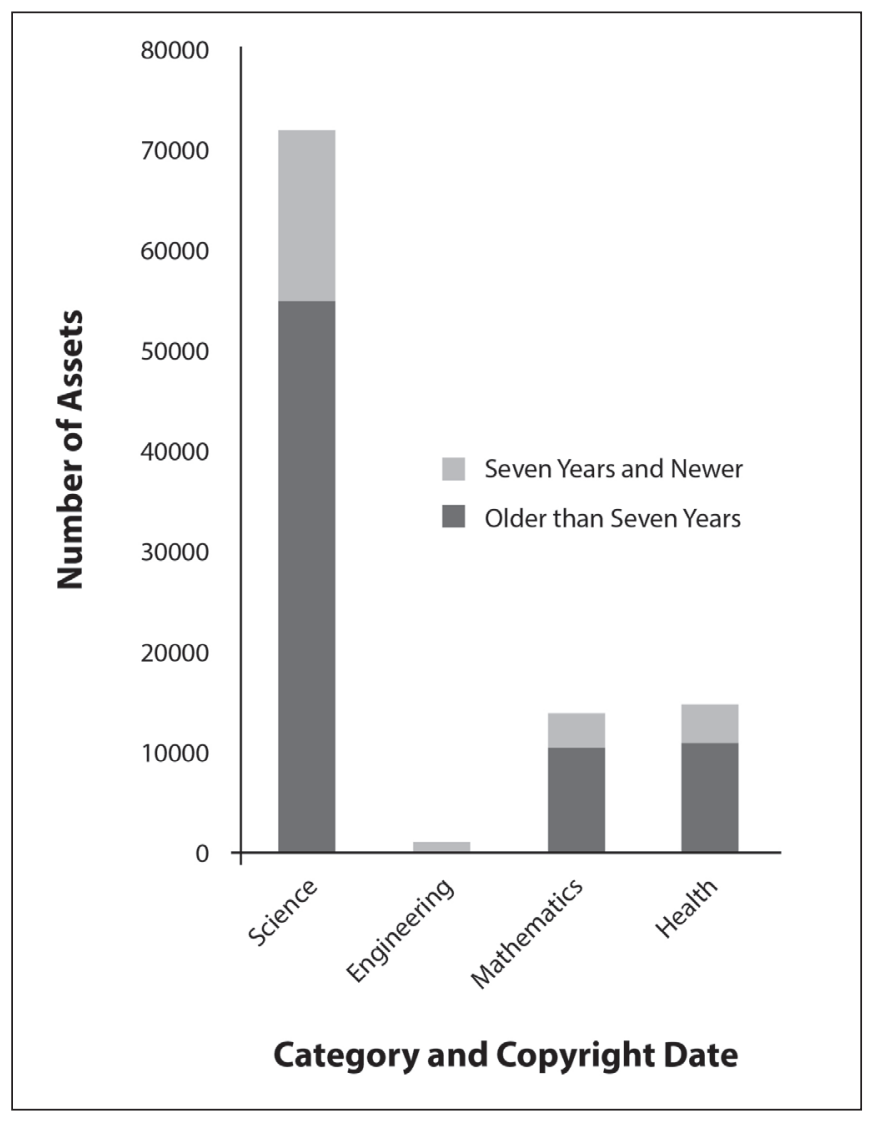

Figure 5. Comparison of All Categories by Copyright Date $(N=100,649)$

ways that school librarians can use Discovery Education Streaming to facilitate the integration of the school library collection and programs. School librarians can foster skills as provided by the American Association of School Librarians' (AASL) Standards for the 21st Century Learner by working cooperatively with students to download, edit, and remix Discovery Education Streaming's multimedia assets. These new assets can then become part of the Discovery Education Streaming's local content and serve as examples for other students and learning resources that can be shared with school administrators, teachers, and parents. These student-created works can serve as starting points for other students pursuing the same subject of study by integrating them with the library catalog. Students can improve their progress toward the AASL Standards' emphases on multimedia literacy and communication skills by investigating scientific advances that have occurred since the creation of some older assets and sharing those discoveries through annotations included in the local Discovery Education Streaming collection.

Discovery Education Streaming and other multimedia databases offer school librarians opportunities to participate in the improvement of STEM education and the transition 
to digital learning materials. Increasingly, definitions of STEM reference an interdisciplinary approach that aims to cultivate a deeper understanding of each subject through an emphasis on the interrelated nature of science, technology, engineering, and math. STEM education also includes process-oriented skills such as scientific inquiry and problem solving. By enhancing these skills, STEM education seeks to build STEM literacy, or "an individual's ability to apply his or her understanding of how the world works within and across four interrelated domains." ${ }^{\text {49 }}$ The integration of Discovery Education Streaming assets into the existing media of the school library collection can help build these interrelationships and promote STEM literacy by allowing students to encounter concepts via multiple media types and observe the relationships of scientific concepts to one another in the context of the school library collection.

\section{References}

1. Keith E. Maull, Manuel Gerardo Saldivar, and Tamara Sumner, "Observing the Online Behavior of Teachers: From Internet Usage to Personalization for Pedagogical Practice," Paper presented at the ACM SIGCHI Conference on Human Factors in Computing Systems, Atlanta, GA, 2010, accessed May 20, 2013, www.academia.edu/366835/Observing_ the_Online_Behavior_of_Teachers_From_Internet_Usage_ to_Personalization_for_Pedagogical_Practice; Anne K. Morris and James Hiebert, "Creating Shared Instructional Products: An Alternative Approach to Improving Teaching," Educational Researcher 40, no. 1 (2011): 5-14, accessed July 1, 2014, http://edr.sagepub.com/content/40/1/5.full.pdf; Kursat Arslan, "Evaluation of Learning Objects from Different Aspects of Effectiveness: Learning, Learning Object Benefit, and Learning Object Quality," in Proceedings of Society for Information Technology \& Teacher Education International Conference 2010, ed. David Gibson, Bernie Dodge (Chesapeake, VA: Association for the Advancement of Computing in Education, 2010), 2143-49.

2. No Dream Denied: A Pledge to America's Children (Washington, DC: National Commission on Teaching and America's Future, 2003); Michael Spaulding, "The Influence of Technology Skills on Preservice and Inservice Teachers' Perceived Ability to Integrate Technology," in World Conference on E-Learning in Corporate, Government, Healthcare, and Higher Education 2010, no. 1, ed. Jaime Sanchez and Ke Zhang (Chesapeake, VA: Association for the Advancement of Computing in Education, 2010) 2193-202.

3. Patricia Montiel-Overall, "Toward a Theory of Collaboration for Teachers and Librarians," School Library Media Research 8, (2005), accessed June 1, 2013, www.ala.org/aasl/ sites/ala.org.aasl/files/content/aaslpubsandjournals/slr/vol8/ SLMR_TheoryofCollaboration_V8.pdf; Empowering Learners: Guidelines for School Library Media Programs (Chicago: American Association of School Librarians, 2009); Nancy
Everhart and Eliza T. Dresang, "School Library Media Specialist for the 21st Century: Leaders in Education Make a Difference," Paper presented at the Association for Library and Information Science Education National Conference, San Antonio, TX, January 17, 2006; School Libraries Work! (Danbury, CT: Scholastic Library Publishing, 2008), accessed May 24, 2013, www2.scholastic.com/content/collateral_resources/ pdf/s/slw3_2008.pdf.

4. Digital Textbook Collaborative, The Digital Textbook Playbook (Washington, DC: Federal Communications Commission, 2012), accessed June 2, 2013, http://transition.fcc.gov/ files/Digital_Textbook_Playbook.pdf.

5. United States Department of Education, Supporting Science, Technology, Engineering, and Mathematics Education: Reauthorizing the Elementary and Secondary Education Act, accessed May 24, 2013, www2.ed.gov/policy/elsec/leg/blue print/faq/supporting-stem.pdf.

6. Ibid.

7. State of Florida, "Senate Bill (SB) 2120: K-12 Education Funding," accessed July 11, 2014, www.flsenate.gov/Session/ Bill/2011/2120.

8. Kathy Mickey and Karen Meaney, Simba Information's 2011 National Textbook Adoption Scorecard and 2012 Outlook (Stamford, CT: Simba Information, 2011).

9. Kathy Mickey et al., K-12 Technology Tools \& Trends 2012 (Stamford, CT: Simba Information, 2012).

10. Lecia Barker, "Science Teachers' Search Behaviors, Resource Preferences, and Classroom Technology," in Proceedings of Society for Information Technology \& Teacher Education International Conference 2010, ed. David Gibson and Bernie Dodge (Chesapeake, VA: Association for the Advancement of Computing in Education, 2010), 1340-45; Henry Braun et al., Exploring What Works in Science Instruction: A Look at the Eighth-Grade Science Classroom (Princeton, NJ: Educational Testing Service, 2009); Richard A. Duschl, Andrew W. Shouse, and Heidi A. Schweingruber, "What Research Says About K-8 Science Learning and Teaching," Education Digest 73, no. 8 (2008): 46-50; Geoffrey Fletcher, Dian Schaffhauser, and Douglas Levin, Out of Print: Reimagining the K-12 Textbook in a Digital Age (Washington, DC: State Educational Technology Directors Association, 2012); Delia R. Duffey and Christine Fox, National Educational Technology Trends 2012: State Leadership Empowers Educators, Transforms Teaching and Learning (Washington, DC: State Educational Technology Directors Association, 2012), accessed July 15, 2013, www.setda.org/wp-content/uploads/2013/12/SETDAN ational_Trends_2012_June20_Final.pdf.

11. Discovery Education, Enhance Your Classroom with Discovery Education Streaming, accessed May 24, 2013, http://dis coveryeducation.com/pdf/DEstreaming_BROCHURE.pdf.

12. Discovery Communications, At a Glance: As Reported July 30, 2013, accessed July 15, 2014, http://media.corporate .discovery.com.s3.amazonaws.com/uploads/pdf/at-a-glance-2 q13-final.pdf. 
13. Thomas D. Snyder and Sally A. Dillow, Digest of Education Statistics, 2012 (Washington, DC: National Center for Education Statistics, Institute of Education Sciences, US Department of Education, 2013).

14. Raymond J. McNulty, "Student Expectations Unmet: Where Are the Electronics?" School Administrator 67, no. 1 (2010): 13; Project Tomorrow, Mapping a Personalized Learning Journey: K-12 Students and Parents Connect the Dots with Digital Learning (Irvine, CA: Project Tomorrow, 2012), accessed July 15, 2013, www.tomorrow.org/speakup/pdfs/SU11_Person alizedLearning_Students.pdf; Project Tomorrow, The New 3 E's of Education: Enabled, Engaged and Empowered: How Today's Students Are Leveraging Emerging Technologies for Learning, accessed July 15, 2014, www.tomorrow.org/speakup/ pdfs/SU10_3EofEducation(Students).pdf

15. Ibid.; Project Tomorrow, Personalizing the Classroom Experience-Teachers, Librarians and Administrators Connect the Dots with Digital Learning, accessed July 15, 2014, www .tomorrow.org/speakup/SU11_PersonalizedClassroom_Edu catorsReport.html.

16. United States Department of Education, Supporting Science, Technology, Engineering, and Mathematics Education, accessed May 24, 2013, www2.ed.gov/policy/elsec/leg/blue print/faq/supporting-stem.pdf.

17. Lawrence Lanahan, "Beyond School-Level Internet Access: Support for Instructional Use of Technology," Education Statistics Quarterly 4, no. 2 (2002), 35-38; Luli Stern and Jo Ellen Roseman," Can Middle-School Science Textbooks Help Students Learn Important Ideas? Findings from Project 2061's Curriculum Evaluation Study: Life Science," Journal of Research in Science Teaching 41, no. 6 (2004): 538-68.

18. Marcia A. Mardis, "School Libraries and Science Achievement: A View from Michigan's Middle Schools," School Library Media Research 10 (2007); Marcia A. Mardis, "Science-Related Topics in School Library Media Periodicals: An Analysis of Electronic Citation Content from 1998-2004," School Libraries Worldwide 12, no. 2 (2006): 1-15.

19. Marcia A. Mardis, "Science Teacher and School Library Media Specialist Roles: Mutually Reinforcing Perspectives as Defined by National Guidelines," in Educational Media and Technology Yearbook, ed. Michael Orey, Vivian McClendon and Robert Maribe Branch (Westport, CT: Libraries Unlimited, 2006): 169-78.

20. Mega Subramaniam et al., "Crosswalk between the 'Framework for K-12 Science Education' and 'Standards for the 21st-Century Learner': School Librarians as the Crucial Link," School Library Research no. 16, accessed July 15, 2014, www.ala.org/aasl/sites/ala.org.aasl/files/content/aaslpubsand journals/slr/vol16/SLR_CrosswalkbetweenFrameworkStandards _V16.pdf; Hanover Research Council, "K-12 STEM Education Overview," accessed June 2, 2013, www.hanoverre search.com/wp-content/uploads/2011/12/K-12-STEM-Edu cation-Overview-Membership.pdf; Office of Educational Technology; United States Department of Education, Office of Technology Education, Transforming American Education: Learning Powered by Technology. National Educational Technology Plan 2010, accessed July 15, 2014, www.ed.gov/ sites/default/files/netp2010.pdf

21. National Research Council, Successful K-12 Stem Education: Identifying Effective Approaches in Science, Technology, Engineering, and Mathematics (Washington, DC: National Academies Press, 2011).

22. Marcia A. Mardis, "Unpacking the Baggage of Collaboration: Some Factors to Consider," Media Spectrum 33, no. 3 (2007): 10-11; Patricia Montiel-Overall, and Kim Grimes, "Teachers and Librarians Collaborating on Inquiry-Based Science Instruction: A Longitudinal Study," Library \& Information Science Research 35, no. 1 (2013): 41-53; Barbara Schultz-Jones and Catherine Ledbetter, "Building Relationships in the School Social Network: Science Teachers and School Library Media Specialists Report Key Dimensions," School Libraries Worldwide 15, no. 2 (2009): 23-48.

23. Ibid.

24. Kay Bishop and Phyllis Van Orden, The Collection Program in Schools: Concepts, Practices, and Information Sources (Westport, CT: Libraries Unlimited, 2007); W. Bernard Lukenbill, Collection Development for a New Century in the School Library Media Center (Westport, CT: Greenwood, 2002).

25. Kathryn L. Bonnell, "Assessing the Use of the Print Collections of Three Suburban High Schools: Implications for Collection Development" (doctoral dissertation, Walden University, 2008).

26. School Libraries Work!, accessed May 1, 2013, www2.scho lastic.com/content/collateral_resources/pdf/s/slw3_2008.pdf.

27. Ibid; Nancy Everhart, Marcia A. Mardis, and Melissa Johnston, "National Board Certified School Librarians' Leadership in Technology Integration: Results of a National Survey," School Library Media Research 14 (2011), accessed July 16, 2014, www.ala.org/aasl/sites/ala.org.aasl/files/content/ aaslpubsandjournals/slr/vol14/SLR_NationalBoardCertified_ V14.pdf.

28. Mardis, "School Libraries and Science Achievement."

29. Marcia A. Mardis and Ellen S. Hoffman, "Collection and Collaboration: Science in Michigan Middle School Media Centers," School Library Media Research 10, (2007), accessed May 22, 2013, www.ala.org/aasl/aaslpubsandjournals/slmrb/ slmrcontents/volume10/mardis_collectionandcollaboration.

30. Mardis, Schoollibraries andscience achievement, accessed May 22, 2013, www.ala.org/ala/aasl/aaslpubsandjournals/slmrb/ slmrcontents/volume10/mardis_schoollibrariesandscience.cfm.

31. Ibid.

32. Project Tomorrow, Unleashing the Future: Educators "Speak up" About the Use of Emerging Technologies for Learning. Speak up 2009 National Findings from Teachers, Aspiring Teachers, and Administrators, accessed May 14, 2013, www .tomorrow.org/speakup/pdfs/SU09UnleashingTheFuture.pdf.

33. Debbie Abilock, "Visual Literacy: Reading a Documentary Photograph," Knowledge Quest 36, no. 3 (2008): 7-13, 
accessed July 17, 2014, http://aasl.metapress.com/content/ n58104h238135346/fulltext.pdf; Tracy L. Coskie and Kimberley J. Davis, "Encouraging Visual Literacy," Science \& Children 46, no. 3 (2008): 56-58, accessed July 17, 2014, http://cmap spublic2.ihmc.us/rid=1H0VWKYQY-1PFL9JT-K54/Encour aging\%20Visual\%20Literacy.pdf; Peter Felten, "Visual Literacy," Change: The Magazine of Higher Learning 40, no. 6 (2008): 60-4; Keith McPherson, "Visual Literacy and School Libraries," Teacher Librarian 32, no. 2 (2004): 58.

34. PBS and Grunwald Associates, Deepening Connections: Teachers Increasingly Rely on Media and Technology, accessed May 24, 2013, www.pbs.org/about/media/about/cms_page_ media/182/PBS-Grunwald-2011e.pdf; Discovery Communications, At a Glance, accessed October 21, 2013, http:// media.corporate.discovery.com.s3.amazonaws.com/uploads/ pdf/at-a-glance-2q13-final.pdf.

35. PBS and Grunwald Associates, Deepening Connections, accessed May 24, 2013, www.pbs.org/about/media/about/ cms_page_media/182/PBS-Grunwald-2011e.pdf.

36. Chih-Ming Chen and Ying-Chun Sun, "Assessing the Effects of Different Multimedia Materials on Emotions and Learning Performance for Visual and Verbal Style Learners," Computers \& Education 59, no. 4 (2012): 1273-85; Lawrence T. Escalada and Dean A. Zollman, "An Investigation on the Effects of Using Interactive Digital Video in a Physics Classroom on Student Learning and Attitudes," Journal of Research in Science Teaching 34, no. 5 (1997): 467-89; Stephan Schwan and Roland Riempp, "The Cognitive Benefits of Interactive Videos: Learning to Tie Nautical Knots," Learning \& Instruction 14, no. 3 (2004): 293-305; Kerry Shephard, "Questioning, Promoting and Evaluating the Use of Streaming Video to Support Student Learning," British Journal of Educational Technology 34, no. 3 (June 2003): 295-308; Randy Yerrick, Donna Ross, and Philip Molebash, "Promoting Equity with Digital Video," Learning \& Leading with Technology 31, no. 4 (2003-4): 16-19.

37. Discovery Communications, At a Glance, accessed October 21, 2013, http://discoveryeducation.com/pdf/DEstreaming BROCHURE.pdf.

38. Discovery Education, Discovery Education Streaming Usage Linked to Top Performing Schools, accessed June 1, 2013, http://static.discoveryeducation.com/feeds/www/media/pdf/ DEstreaming_Usage Achievement Overview.pdf; Franklin J. Boster et al., "The Impact of Video Streaming on Mathematics Performance," Communication Education 56, no. 2 (April 2007): 134; Franklin J. Boster, Use of Discovery Education Science and school performance: Charlotte/Mecklenburg, 2012, accessed May 24, 2013, http://static.discovery education.com/feeds/www/media/pdf/DEScience_School\%20 Performance.pdf.

39. Marcia A. Mardis, "Viewing Michigan's Digital Future: Results of a Survey of Educators' Use of Digital Video in the United States," Learning, Media \& Technology 34, no. 3 (2009): 243-57, dx.doi.org/ 10.1080/17439880903141539.
40. Robin H. Kay and Liesel Knaack, "Evaluating the Use of Learning Objects for Secondary School Science," Journal of Computers in Mathematics \& Science Teaching 26, no. 4 (2007): 261-89; Eric N. Wiebe, Aaron C. Clark, and Eleanor V. Hasse, "Scientific Visualization: Linking Science and Technology Education through Graphic Communications," Journal of Design \& Technology Education 6, no. 1 (2001): 40-47, accessed July 17, 2014, http://ojs.lboro.ac.uk/ojs/index.php/ JDTE/article/view/434/411; Hsin-Kai Wu, Joseph S. Krajcik, and Elliot Soloway, "Promoting Understanding of Chemical Representations: Students' Use of a Visualization Tool in the Classroom." Journal of Research in Science Teaching 38, no. 7 (2001): 821-42.

41. Nancy Everhart et al., From District to Desktop: Making the Most of Broadband in Schools, accessed July 17, 2014, www.nsf.gov/sbe/sbe_2020/2020_pdfs/Everhart_Nancy _32.pdf; Warren R. Goetzel, "The Role of Media Specialists with Respect to Instructional Technology in an Urban School District in Georgia” (doctoral dissertation, Georgia State University, 2012), http://scholarworks.gsu.edu/cgi/view content.cgi? article $=1096 \&$ context $=$ msit_diss; Shirley Benson McDonald, "The Role of Technology in the Interactions between Secondary School Library Media Specialists and Teachers" (doctoral dissertation, Louisiana State University, 2006), http://etd.lsu.edu/docs/available/etd-04022006 -211850/unrestricted/McDonald_dis.pdf.

42. Marcia A. Mardis, Infusing Science into Middle School Media Centers: Obstacles and Strategies: A Final Report for the Institute for Library and Information Literacy Education (ILILE) National Research Grant Program, accessed May 20, 2013, www.ilile.org/initiatives/grants/final_reports/ easternmichiganuniversity.pdf; Marcia A. Mardis and Ellen S. Hoffman, "School Library Factors Affecting Science Achievement," (paper presented at the American Educational Research Association, Chicago, IL, April 10, 2007).

43. Ibid.

44. Ibid; Anna L. Ball, Neil A. Knobloch, and Sue Hoop, "The Instructional Planning Experiences of Beginning Teachers," Journal of Agricultural Education 48, no. 2 (2007): 56-65; Sue Bennett, Lori Lockyer, and Ian Brown, "Investigating the Factors That Influence the Use of Digital Learning Resources in the K-12 Educational Context," in Proceedings of the World Conference on Educational Multimedia, Hypermedia and Telecommunications 2005, Montreal, Canada, ed. Piet Kommers and Griff Richards (Chesapeake, VA: Association for the Advancement of Computing in Education, 2005): 2391-403; Anne Diekema and M. Whitney Olsen, "Personal Information Management Practices of Teachers," in Proceedings of the American Society for Information Science and Technology Annual Conference (New Orleans: American Society for Information Science and Technology, 2011): 1-10; Katherine Hanson and Bethany Carlson, Effective Access: Teachers' Use of Digital Resources in STEM Teaching (Newton, MA: Education Development Center, 2005); Louanna 
Ione Smolin, and Kimberly A. Lawless, "Becoming Literate in the Technological Age: New Responsibilites and Tools for Teachers," Reading Teacher 56, no. 6 (2003), 570-77; Marcia A. Mardis et al., "The Digital Lives of U.S. Teachers: A Research Synthesis and Trends to Watch," School Libraries Worldwide 18, no. 1 (2012): 70-86; Anne Marie Perrault, “An Exploratory Study of Biology Teachers' Online Information Seeking Practices," School Library Media Research 10 (2007), accessed July 21, 2014, http://files.eric.ed.gov/fulltext/EJ851701.pdf; Elizabeth Probert, “An Investigation into the Teaching of Information Literacy Skills by Teachers in New Zealand Secondary Schools," in IASL Reports 2006: Reading, Knowledge, Doing, the Multiple Faces of Literacy : Papers from the 35th Annual Conference of the International Association of School Librarianship, ed. Ana Bela Martins et al. (Erie, PA: International Association of School Librarianship, 2006); Dorothy Williams and Louisa Coles, The Use of Research Information by Teachers: Information Literacy, Access and Attitude: Final Report (Aberdeen, Scotland: Robert Gordon University, 2003); Teresa D. Williams, Bonnie J. Grimble, and Marilyn Irwin, “Teachers' Link to Electronic Resources in the Library Media Center: A Local Study of Awareness, Knowledge, and Influence," School Library Media Research 7 (2004).
45. Marcia A. Mardis and Anne M. Perrault, "Examining the Information Behaviors of Educators to Inform a Model of Professional Exchange between Science Teachers and Library Media Specialists," paper presented at the American Educational Research Association, Chicago, April 10, 2007; Anne Marie Perrault, "The School as an Information Ecology: A Framework for Studying Changes in Information Use," School Libraries Worldwide 13, no. 2 (2007): 49-62.

46. Hanover Research Council, District Administration Practice: Technology Usage and Staffing, accessed June 1, 2013, www .hanoverresearch.com/toolkit/pdf/Technology-Usage-andStaffing-in-Public-School-Districts-Membership.pdf.

47. Erik Drake, "The Teaching and Partnering Responsibilities of Michigan School Library Media Specialists," Media Spectrum 33, no. 3 (2007): 46-54; Warren R. Goetzel, "The Role of Media Specialists with Respect to Instructional Technology in an Urban School District in Georgia” (doctoral dissertation, Georgia State University, 2012); Melissa Johnston, “Connecting Teacher Librarians for Technology Integration Leadership," School Libraries Worldwide 18, no. 1 (2012): 1-11.

48. David D. Thornburg, "Why STEM Topics Are Interrelated: The Importance of Interdisciplinary Studies in K-12 Education," accessed July 22, 2014, www.tcse-k12.org/pages/stem.pdf.

49. Ibid.

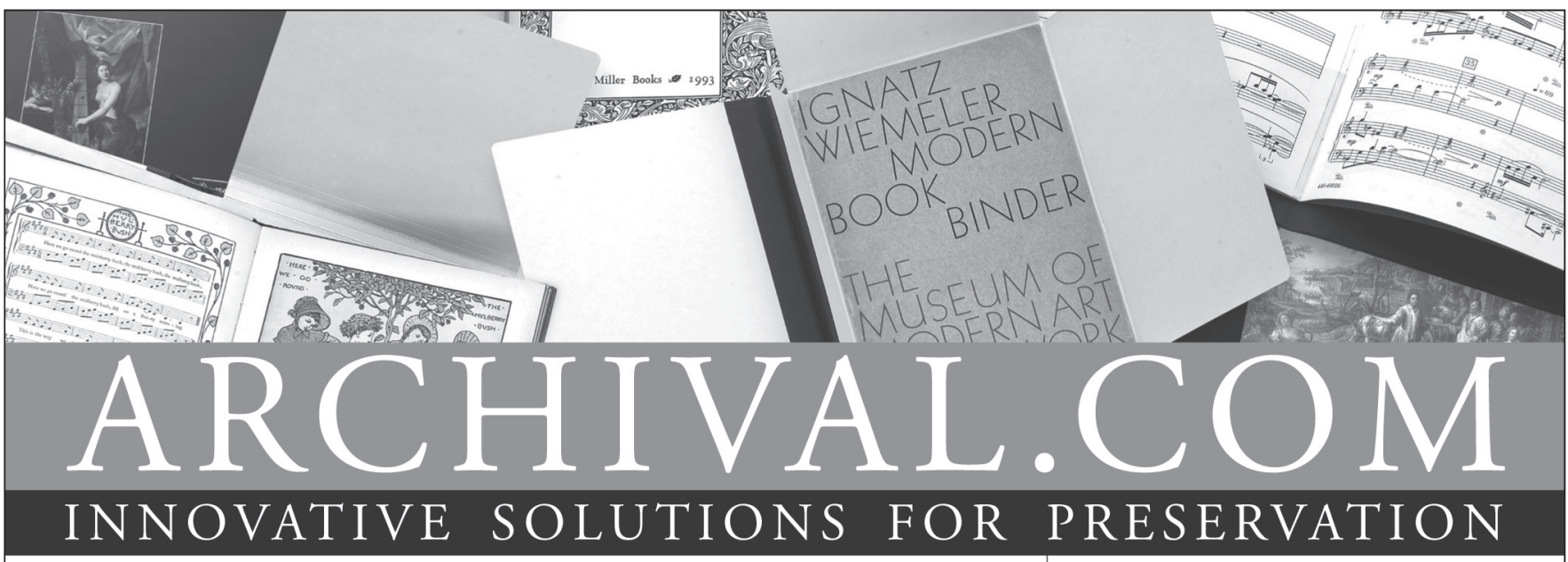

Call for a complete catalog

Pamphlet Binders Music Binders Archival Folders Manuscript Folders Hinge Board Covers Academy Folders Newspaper/Map Folders Bound Four Flap Enclosures Archival Binders
Polypropylene Sheet \& Photo Protectors Archival Boards Adhesives Bookkeeper Century Boxes Conservation Cloths Non-Glare Polypropylene Book Covers

CoLibri Book Cover System

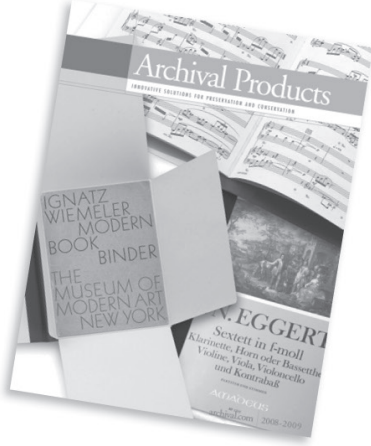

ARCHIVAL PRODUCTS

P.O. Box 1413

Des Moines, Iowa 50306-1413

Phone: 800.526.5640

Fax: 888.220.2397

E-mail: custserv@archival.com Web: archival.com 